\section{The Moderating Role of Consumer Characteristics on E-Loyalty in E-banking business: A Multigroup Analysis}

\author{
Chaima Aziza, \\ 74551275@uofn.edu.om \\ Norizan Mohd Kassim (Corresponding author) \\ nkassim@unizwa.edu.om \\ Department of Management \\ College of Economics, Management and Information Systems \\ University of Nizwa, Oman
}

\begin{abstract}
Noticing the recent development in internet banking in different parts of the world has resulted in increasing online transactions without visiting the bank. Thus, this study investigates the importance of antecedents of e-loyalty-shared value, information quality, system quality, service quality, trust, attraction, and satisfactionin using e-banking services and the role of consumer characteristics (gender, age, and level of education) as a moderator was analyzed as well. A survey questionnaire was distributed conveniently via online and face-to-face to customers in Muscat and Nizwa to gain important insights on how customer loyalty in the e-banking business is constructed. A total of 228 usable questionnaires were collected and analyzed using descriptive statistics, multigroup analysis, and structural equation modelling to test the hypotheses. Results of the analyses indicated that eloyalty is found to be positively influenced by satisfaction, which later influenced by trust, attraction, shared value, information quality, system quality, service quality. The moderating role of gender, age, and level of education was supported by the data. The paper concludes some implications and limitations of the results are discussed. Besides, investigating which factors are important in driving customers using online banking, this study provides a deeper understanding of keeping customers online and loyal to a particular service provider. Specifically, the service providers need to focus on the importance of gender, age, and level of education in moderating the construction of e-loyalty in using e-banking services. This study provides new insights by adding attraction as an antecedent of customer satisfaction and the moderating role of consumer characteristics in using e-banking services.
\end{abstract}

Keywords- E-Loyalty, E-Banking, Structural Equation Modeling, Multigroup Analysis, Oman.

\section{INTRODUCTION}

The rapid growth in the usage of the internet in all business activities has been tremendous recently. Particularly, one of the internet technologies has changed the way banks provide their services and customers managed their personal financial needs through the internet banking services. Internet banking has increasingly become a favorable distribution channel by service providers and customers alike. e-banking system allows customers to conduct all the traditional banking services without visiting their bank branch. However, the absence of personal contact gives customers a feeling of uncertainty and risk (Reichheld \& Schefter, 2000). Therefore, a good security system helps in building customers' trust in performing ebanking transactions (Cappelli \& Clancy, 1999).

According to Echchabi, Al-Hajri, \& Tanas, (2019) having a developed and secure e-banking system contributes in enhancing the performance and efficiency of banks, and attracting and retaining customers as well. Moreover, ebanking helps banks to expand their market reach and product breadth at a low cost. Moreover, the bank websites offer portals connecting customers to a host of financial products, and thus, increasing marketing opportunities. In fact, internet banking is also known as electronic banking (e-banking), online banking, web banking, and virtual banking (Echchabi, Al-Hajri, \& Tanas, 2019). For the purpose of and throughout this research we will use the term internet banking and e-banking interchangeable.

Obviously, what it is essential for the bank is keeping its customers because it is less expensive than to attract the new ones (Reichheld \& Schefter, 2000), that is to increase its customer share, not the number of customers. Loyal customers have been always important but the ways in which customers develop loyalty is unclear, especially when the internet is involved (Jansson \& Letmark, 2005). Unfortunately, fairly little has been written in this domain.

Thus, this study contributes to the body of knowledge in the trust-relationship model use of technology by developing a comprehensive model on the management of personal finance through e-banking. The following section reviews previous academic literature along with identifying the main research problem, variables, and the proposed theoretical framework.

\section{Literature Review}

In this section, the review of literature begins with an overview of previous e-banking research in continuous usage (commitment-trust model) and loyalty. A theoretical framework relating to important determinants of loyalty and a number of mediating variables is discussed. 


\begin{abstract}
Shared Value
According to Morgan and Hunt (1994) shared value is a stage where business partners have beliefs about behavior, goals and regulations. In the context of e-banking, shared values portray consumers' confidence towards values such as ethics, security and privacy (Mukherjee \& Nath, 2003; Kassim \& Abdulla, 2006). Security has an important role in ensuring the safety of customer and that prevent hackers from the invasion of their customer's privacy. in fact, security in internet banking had a positive and significant effect on customer satisfaction.
\end{abstract}

Indeed, previous studies (Matemba \& Li, 2018; Sharma \& Lijuan, 2014) stated that perceived security refers to the ethical dimension of internet banking users regarding the financial transactions carried out over the internet. It is the risk related to the stealing of financial information by unauthorized personnel, virus attacks, and the installation of malicious software. Thus, as Limbu, Wolf, and Lunsford, (2011) pointed out that internet banking users expected that the mobile applications or website to be fully secured against any unauthorized personnel in order to ensure that the financial detailed are secured properly and not shared or stored in any form.

Next, privacy is considered as a critical element which always a concern to the internet banking customers. Where, they are always hoping to be protected by the bank especially when they are using their personal and financial information in doing different online transaction through the internet banking (Ahmad \& Al-Zu' i, 2011). Moreover, perceived privacy has been found to be the determinant factor of customer willingness for the usage and trust of technology (Arpaci, 2016; Khasawneh et al., 2018; Ozturket al., 2017; Zhang, Lu, \& Kizildag, 2018).

\section{Communication}

Additionally, favourable communication environment may also affect and foster users' trust in e-banking services. Hence, in this study the communication in e-banking includes dimensions such as system quality, information quality, service quality and user interface (Gao \& Waechter, 2017; Silic \& Ruf, 2018) These dimensions will be discussed next.

First, according to Silic and Ruf, (2018) that the first impression of e-banking users is on many factors such as mobile platforms facelessness, speed access, navigation, and visual appeal. It is evident in the previous studies (Gao \& Waechter, 2017; Silic \& Ruf, 2018; Zhou, 2011d, 2012b) that users develop a high level of trust only when they received a system with high quality and resulted of them spending more on that particular system.

Second, information quality on hand is the reflection of information relevance, sufficiency, accuracy, and timeliness that are provided by mobile banking systems. Users while using any mobile banking system usually they search for various type of information. Thus, information quality plays a very important role in trust in mobile banking, and financial services have as highlighted by extant research (Silic \& Ruf, 2018). Across different recent studies in internet banking, researchers have found and agreed that information quality is significantly influenced trust.

Third, offering users good quality of e-banking services is vital as well. Service quality in this regard is defined as the ability of a particular system in offerings to the users in terms of its reliability, responsiveness, assured assurance and personalized services (Gao \&Waechter, 2017). Service reliability refers to high-quality services that enables the users in building trust in the system (Apostolos, 2016; Wang et al., 2019). Extant studies (such as Ofori et al., 2018; Silic \& Ruf, 2018) have found that service quality is one of the users' trust determinants. Accordingly, when users experienced exceed a certain level of service quality, the trust form of users is as they perceive the offered service to be competent (Puriwat \& Tripopsakul, 2017). It is evident that untimely and unreliable services led to building the users' distrust about the system (Apostolos, 2016; Gao \& Waechter, 2017; Ofori et al., 2018; Puriwat \& Tripopsakul, 2017; Silic \& Ruf, 2018).

Finally, in internet banking, the user interface is known as the environment of the users which includes various functions such as menus and options (Stewart \& Jürjens, 2018). Previous literature on the formation of trust in internet banking disclosed that the user interface design is considered as one of the important factors that affect user's trust in the system. Stewart and Jürjens, (2018) confirmed previous literature where they stated that a well-design user interface helps in reducing the complexity, facilitates navigation and interactivity and builds the user's trust in using the system.

\section{Attraction}

The attraction variable has received little attention in the service-marketing literature that related to customer loyalty decisions (Gronroos, 2001; Kassim \& Abdulla, 2006). They further suggested that attraction to a given customer means that there should be something that makes the service provider fascinating that can be built on financial, technology or social constructs (Gronroos, 2001; Kassim \& Abdulla, 2006; Sathye, 1999). In the context of internet banking, customers can save on the transaction handling fees and costs associated with performing their financial activities (see Sathye, 1999). Moreover, ease of use element is necessary for customer usage of computer technologies, especially for new users (Davis, 1989; Ribbink et al., 2004). For example, the interaction with e-banking does not require a lot of mental effort, and customers can easily access e-banking services whenever they want, and it enables them to conduct their banking transactions quickly. It is evident in the previous study that attraction has a strong positive effect on relationship commitment in e-banking with communication having the most important determinant of attraction (Kassim \& Abdulla, 2006). 


\section{Trust, Satisfaction and Loyalty}

The following section highlights the relevant literature on the concept of trust, satisfaction, and loyalty.

According to the Cambridge Dictionary, trust is defined as something is safe and reliable. Thus, it an important construct in many transactional relationships. Morgan and Hunt (1994) found that trust exists in the case of one party has confidence in the reliability and integrity of the exchange partners. The authors also regarded trust as a predictor of customer's future intentions. The previous study by Kesharwani and Bisht (2012) found that trust has an important role in creating satisfied and expected outcomes as a result of transactions. It is recognized to be one of the most critical factors for any online environment to succeed (Benbasat et al., 2010).

In the technology acceptance model, trust has been conceptualized as a dimension that influence users' willingness to engage in online exchanges of money and personal sensitive information (Kassim \& Abdulla, 2006). A recent study by Rizomyliotis, Konstantoulaki, Kaminakis, Giovanis, and Papastathopoulos (2018) has found that customer satisfaction is significantly related to trust, while trust is the predictor to customer loyalty in mobile telecommunication market.

Next, satisfaction can be defined as the difference between customer expectation and performance of the service provided and is mostly used as part of the confirmation/disconfirmation paradigm (Oliver \& Swan 1989). In other words, a customer is said to be satisfied if the perceived performance of service meets or exceeds his or her expectations or dissatisfied if the perceived performance did not meet his or her expectations of the service provided. In previous studies, customer satisfaction has been regarded solely as a result of cognitive processes. However, in the context of the relationship between satisfaction and loyalty, satisfaction is based on the customer's cumulative experience (Anderson et al. 1994). Satisfaction with a single transaction does not result in long-term loyalty, neither does dissatisfaction transaction lead to customer switching. Therefore, the enhancement of the knowledge regarding internet banking and customer perceptions toward it has become important for banks to be more competitive in providing an effective and efficient internet banking system (Zheng, Men, Yang, \& Gong, 2019).

Finally, in the previous study by Anderson and Srinivasan (2003) defines customer loyalty in using a system as the customer tendency to re-dealing with a particular service and frequently visit it. For this reason, Gera (2011) assumed that interaction experience with the web site is considered as one of the most critical in affecting the customer's decision to revisiting the web site and also to recommend others. Caruana (2002) and Baumann et al. (2012) stated that customer previous experience of a particular service is important in the development of customer attitude toward re-dealing with that service. Consequently, focusing on customer loyalty is critical for internet banking for marinating the relations with their customers. In this context, a customer with a high level of loyalty will frequently visit the web site and spreading positive comments and recommending others to use the system as well when it comes to making decisions to patronize a financial institution (Amin et al., 2011; Caruana, 2002; Kaur \& Soch, 2012). In other words, this leads to a high commitment to redealing consistently with the same service provider in the future (Anderson and Swaminathan, 2011; Fraering and Minor, 2013; Kandampully et al., 2015; Ladhari et al., 2011; Melnyk and Bijmolt, 2015).

We included user characteristics such as gender, age, and level of education as moderators in our model. Floh and Treiblmaier (2006) reported and supported the findings of Homburg and Giering (2001) regarding the impact of service quality has on satisfaction for younger people than for the elderly.

Thus, based on the above background, this research project addresses: how to keep the e-banking user online and loyal? This justifies the need for the present study to investigate the determinants of users' patronage with internet banking. Thus, the objectives of this research paper are:

- to investigate the importance of antecedents of e-loyaltyinformation quality, system quality, service quality, trust, attraction, and satisfaction - in using e-banking services and

- to examine the role of consumer characteristics (gender, age, and level of education) as a moderator.

Based on the above discussions of the previous reviews of literature, we develop a theoretical framework as shown in Figure 1 that links the trust and attraction to the users' satisfaction and loyalty.

The first link examines the influence of shared value, information quality, system quality and service quality on trust. Second link examines the influence of information quality, system quality and service quality on attraction. Third and fourth links examine the influence of trust and attraction on users' satisfaction. The fifth and sixth links examine the influence of trust and satisfaction on users' loyalty. Finally, the moderation effect of demographic characteristic on the relationship between shared value, information quality, system quality and service quality and trust and between information quality, system quality and service quality and attraction, between trust and satisfaction, between attraction and satisfaction and between trust and loyalty and between satisfaction and loyalty.

The research variables in this study are drawn from the works of existing literatures (Gao \& Waechter, 2017; Kassim \& Abdulla, 2006; Mukherjee \& Nath 2003; Yuan, Lai, \& Chu, 2019). Based on the proposed theoretical framework, the hypotheses were developed as shown in Table 1. 
III. Proposed Theoretical Framework AND HYPOTHESIS

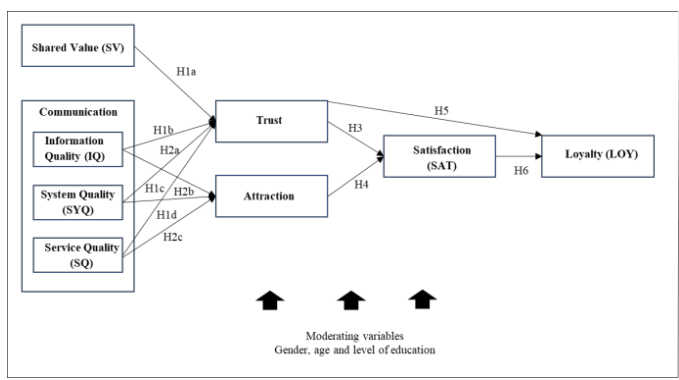

Figure 1. Proposed theoretical framework

(Source: Gao \& Waechter, 2017; Kassim \& Abdulla, 2006; Mukherjee \& Nath 2003; Yuan, Lai, \& Chu, 2019)

Table 1 Hypotheses

\begin{tabular}{ll}
\hline Hypothesis & Description \\
\hline $\mathrm{H}_{\mathrm{a}, \mathrm{b}, \mathrm{c} \text { and } \mathrm{d}}$ & $\begin{array}{l}\text { Shared value, information quality, system } \\
\text { quality, and service quality influence user trust } \\
\text { in e-banking services }\end{array}$ \\
$\mathrm{H} 2_{\mathrm{a}, \mathrm{b} \text { and c }}$ & $\begin{array}{l}\text { Information quality, system quality, and } \\
\text { service quality influence user attraction in e- } \\
\text { banking services }\end{array}$ \\
$\mathrm{H} 3$ & $\begin{array}{l}\text { Trust influences user satisfaction in e-banking } \\
\text { services }\end{array}$ \\
$\mathrm{H} 4$ & $\begin{array}{l}\text { Attraction influences user satisfaction in e- } \\
\text { banking services } \\
\text { Trust influences user loyalty in e-banking } \\
\text { services }\end{array}$ \\
$\mathrm{H} 6$ & $\begin{array}{l}\text { Satisfaction influences user loyalty in e- } \\
\text { banking services } \\
\text { Demographic characteristics moderate the } \\
\text { relationship of H1- H6 }\end{array}$ \\
$\mathrm{H} 7$ &
\end{tabular}

\section{SIGNIFICANCE OF THE STUDY}

Gaps in the literature. The review of the literature described above clearly indicates some gaps in the literature, which justify this research. Numerous studies have undertaken to identify the factors affecting adopters and/or users of internet banking (see Echchabi, Al-Hajri, \& Tanas, 2019; Musaev \&Yousoof, 2015; Al-Sabbagh \& Alemayehu, 2004) and very few studies on the factors affecting users' patronage with internet banking, specifically in Oman. Hence, the present study provides additional insights into this domain. Moreover, understanding the role of attraction in a customer loyalty decision has received little attention in the service-marketing literature (Gronroos, 2001; Kassim \& Abdulla, 2006).

Size and changes in the industry. A strong e-banking system is essential in the current business world and is aligned with the Sultanate's vision for a sustainable economy that is fully digitalized which is reflected clearly in the rapid growth of ebanking services in Oman.

Potential benefits. The model adopted in this research project poses that the acceptance factors may be strengthened so the users of the system can find it convenient, easy to use, hasslefree, and accessible. Hence, the results of this study will give empirical and substantive information about internet banking adoption and acceptance by the identification of the relevance of all factors in internet banking. It also provides an integrated framework that merged various internet banking attributes and highlights these dimensions' applicability in using internet banking services. The findings of this study will shed lights on Oman's banking industry to offer an effective internet banking platform that harnesses the internet banking advantages by focusing on the important relevant factors in this particular culture. In conclusion, this research is justified on the above three conceptual and practical perspectives.

\section{Methodology}

Since the objective of this study is to investigate the effects of internet banking on customer loyalty and to examine the demographic characteristics as a moderator on these effects, a hypothesis testing approach will be used in this study for generalizing the results to the population. Next, the survey questionnaire was developed using constructs and items adapted from existing academic literature (Gao \& Waechter, 2017; Kassim \& Abdulla, 2006; Mukherjee \& Nath 2003; Yuan, Lai, \& Chu, 2019) and tailored to suit the main objectives of this research project. Each item was measured using fivepoint Likert-type scales ranging from agreeing to disagree.

Table 2 Measurements used in this research

\begin{tabular}{|c|c|c|c|}
\hline \multirow{4}{*}{$\begin{array}{l}\text { Construct } \\
\text { Shared value }\end{array}$} & Item & Description & Factor loadings \\
\hline & SV1 & $\begin{array}{l}\text { My e-banking site protects information about my } \\
\text { onsite behavior }\end{array}$ & 0.73 \\
\hline & SV2 & My e-banking is safe to use for my banking & 087 \\
\hline & SV3 & $\begin{array}{l}\text { Security guidelines are displayed before using my e- } \\
\text { banking }\end{array}$ & 0.57 \\
\hline \multirow[t]{4}{*}{$\begin{array}{l}\text { Information } \\
\text { quality }\end{array}$} & IQ1 & $\begin{array}{l}\text { E-banking provides me with information relevant to } \\
\text { my needs }\end{array}$ & 0.75 \\
\hline & IQ2 & E-banking provides me with sufficient information. & 0.77 \\
\hline & IQ3 & E-banking provides me with accurate information & 0.73 \\
\hline & IQ4 & E-banking provides me with up-to-date information & 0.71 \\
\hline \multirow[t]{4}{*}{ System quality } & $\mathrm{SYQ1}^{*}$ & E-banking quickly loads all the text and graphics & Deleted \\
\hline & SYQ2 & E-banking is easy to use. & 0.85 \\
\hline & SYQ3 & E-banking is easy to navigate & 0.76 \\
\hline & SYQ4 & E-banking is visually attractive & 0.68 \\
\hline \multirow[t]{4}{*}{ Service quality } & SQ1 & E-banking provides on-time services. & 0.76 \\
\hline & SQ2 & E-banking provides prompt responses & 0.75 \\
\hline & SQ3 & E-banking provides professional services & 0.75 \\
\hline & SQ4 & E-banking provides personalized services & 0.73 \\
\hline \multirow[t]{4}{*}{ Attraction } & ATRN1* & $\begin{array}{l}\text { The interaction with e-banking does not require a lot } \\
\text { of mental effort. }\end{array}$ & Deleted \\
\hline & ATRN2* & $\begin{array}{l}\text { Saving the transaction handling fees in performing my } \\
\text { banking transaction. }\end{array}$ & Deleted \\
\hline & ATRN3 & I can access e-banking whenever I want. & 0.77 \\
\hline & ATRN4 & E-banking enables me to conduct my banking & \\
\hline \multirow{3}{*}{ Trust } & $\mathrm{T} 1$ & $\begin{array}{l}\text { transactions quickly. } \\
\text { Can be counted on }\end{array}$ & 0.78 \\
\hline & $\mathrm{T} 2$ & Has my confidence & 0.88 \\
\hline & $\mathrm{T} 3$ & The bank has high integrity & 0.79 \\
\hline \multirow[t]{4}{*}{ Satisfaction } & SAT1 & I am satisfied with the e-banking & 0.82 \\
\hline & SAT2 & I am pleased with in e-banking & 0.85 \\
\hline & SAT3 & I am contented with e-banking & 072 \\
\hline & SAT4 & I am delighted e-banking & 0.75 \\
\hline \multirow[t]{5}{*}{ E-Loyalty } & LOY1 & $\begin{array}{l}\text { I would continue to use e-banking for my banking } \\
\text { needs }\end{array}$ & 0.79 \\
\hline & LOY2 & Continuing to use the e-banking for handling my & 090 \\
\hline & LOY3 & I would continue to see myself using the e-banking for & \\
\hline & LOY4* & $\begin{array}{l}\text { handling my banking transactions } \\
\text { I believe I could communicate to others the }\end{array}$ & $\begin{array}{c}0.87 \\
\text { Deleted }\end{array}$ \\
\hline & LOY5 & $\begin{array}{l}\text { consequences of using e-banking } \\
\text { I would have no difficulty telling others about the }\end{array}$ & 0.69 \\
\hline
\end{tabular}


The sample consisted of both Omani and non-Omani population especially those who are having a bank account and who have or have not used internet banking were included in the sample. The questionnaire was conveniently distributed due to time constraints, in doing this research and the costs involved.

Finally, data were analyzed using SPSS software version 24 and AMOS version 20 software. Types of analyzing data used in this study were descriptive analysis (SPSS software version 24) and inferential analysis using structural equation modeling (SEM), and Multigroup analysis using AMOS version 20.

\section{Results}

A total of 228 usable questionnaires were collected online through SurveyMonkey and face to face. The data were analyzed using descriptive statistics, multigroup analysis, and structural equation modeling to test the hypotheses. The majority of the respondents were female (61.8percent) aged between 25 to 44 years old ( 71.5 percent) and obtained at least a bachelor's degree (43.9 percent). One possible explanation for this issue is that women outnumbered men at universities and college (Viswanathan, 2017). Moreover, the majority of the data consisted of employees (both non-academic and academic) and students at universities and colleges.

The initial CFA model for system quality was not acceptable, and one item was eliminated to achieve an acceptable fit as shown in table 3 (Anderson \& Gerbing, 1988).

$\underline{\text { Table } 3 \text { Constructs' reliability }}$

\begin{tabular}{llccc}
\hline Construct & Source & $\begin{array}{c}\text { No. of } \\
\text { original item }\end{array}$ & $\begin{array}{c}\text { No. of } \\
\text { retained item }\end{array}$ & $\begin{array}{c}\text { Corrected } \\
\text { alpha }\end{array}$ \\
\hline Shared value & Mukherjee and Nath (2003) & 3 & 3 & 0.69 \\
Information quality & Gao and Waechter (2017) & 4 & 4 & 0.83 \\
System quality & Gao and Waechter (2017) & 4 & 3 & 0.80 \\
Service quality & Gao and Waechter (2017) & 4 & 4 & 0.82 \\
Attraction & Kassim and Abdulla (2006) & 4 & 2 & 0.80 \\
Trust & Yuan, Lai, and Chu (2019) & 4 & 3 & 0.84 \\
Satisfaction & Yuan, Lai, and Chu (2019) & 4 & 4 & 0.88 \\
E-Loyalty & Yuan, Lai, and Chu (2019) & 5 & 4 & 0.86
\end{tabular}

The results in table 4 indicate the psychometric properties of each scale with the goodness of fit indices fit the data very well with $\chi 2(\mathrm{CMIN} / \mathrm{df})=2.1, \mathrm{CFI}=0.93$, and $\mathrm{RMSEA}=$ 0.06. Moreover, the results in table 2 demonstrate adequate discriminant validity of the constructs with all the average variance extracted (AVE) exceeded the minimum level of 0.50 (Fornell \& Larcker, 1981).
Table 4 Psychometric poperties of the measurement scales

\begin{tabular}{|c|c|c|c|c|c|c|c|c|c|c|c|c|}
\hline & Mean & SD & $\alpha$ & CR & MSV & MIQ & MSYQ3 & MSQ & MATRN2 & MTRT & MSAT & MLOY \\
\hline MSV & 3.94 & 0.66 & 0.69 & 0.77 & 0.54 & 0.44 & 0.34 & 0.33 & 0.26 & 0.29 & 0.33 & 0.44 \\
\hline MIQ & 3.92 & 0.72 & 0.83 & 0.83 & & 0.55 & 0.46 & 0.48 & 0.35 & 0.39 & 0.43 & 0.44 \\
\hline MSYQ3 & 3.90 & 0.77 & 0.80 & 0.81 & & & 0.59 & 0.54 & 0.47 & 0.35 & 0.48 & 0.47 \\
\hline MSQ & 3.87 & 0.69 & 0.82 & 0.84 & & & & 0.56 & 0.43 & 0.47 & 0.55 & 0.50 \\
\hline MATRN2 & 3.93 & 0.76 & 0.77 & 0.78 & & & & & 0.60 & 0.36 & 0.53 & 0.48 \\
\hline MTRT & 3.84 & 0.74 & 0.84 & 0.84 & & & & & & 0.64 & 0.53 & 0.48 \\
\hline MSAT & 3.87 & 0.79 & 0.88 & 0.87 & & & & & & & 0.62 & 0.62 \\
\hline MLOY & 4.00 & 0.75 & 0.86 & 0.89 & & & & & & & & 0.67 \\
\hline \multicolumn{13}{|c|}{$* *$ All are significant at $p<0.01$ level (2-tailed). } \\
\hline \multicolumn{13}{|c|}{ Note: Diagonal value is AVE and values above the diagonal are squared correlations } \\
\hline \multicolumn{13}{|c|}{$\mathrm{CR}=$ Composite reliability; $\mathrm{MSV}=$ Shared value; $\mathrm{MIQ}=$ Information Quality; $\mathrm{MSYQ} 3=$ System Quality } \\
\hline \multicolumn{13}{|c|}{ MATRN2 = Attraction; MT3 = Trust; MSAT = Satisfaction; MLOY4 = E-Loyalty } \\
\hline
\end{tabular}

Additionally, we conducted Harman's Single Factor Test through exploratory factor analysis (Podsakoff et al, 2003) to estimate the common method bias. The result suggests that there is no significant common method bias in this data since the calculated variance is 47.8 percent that is below 50 percent. The results in table 5 indicate that e-loyalty is found to be positively influenced by satisfaction, which later influenced by trust and attraction. Trust is influenced by the shared value and service quality, while attraction is influenced by system quality and service quality.

\begin{tabular}{|c|c|c|c|c|c|c|c|}
\hline Hypothesi & & Path: & & \multirow{2}{*}{$\frac{\text { Estimate } \beta}{0.257}$} & \multirow{2}{*}{$\frac{T \text { _value }}{2.264}$} & \multirow{2}{*}{$\frac{P \text { _value }}{0.024^{* *}}$} & \multirow{2}{*}{$\begin{array}{l}\text { Result } \\
\text { Accepted }\end{array}$} \\
\hline $\mathrm{Hla}$ & MSV & $\rightarrow$ & MT3 & & & & \\
\hline $\mathrm{Hlb}$ & MIQ & $\rightarrow$ & MATRN2 & 0.120 & 0.931 & ns & Rejected \\
\hline $\mathrm{Hlc}$ & MSYQ3 & $\rightarrow$ & MATRN2 & 0.353 & 2.415 & $0.016^{* *}$ & Accepted \\
\hline Hld & MSQ & $\rightarrow$ & MATRN2 & 0.444 & 2.498 & $0.012^{*}$ & Accepted \\
\hline $\mathrm{H} 2 \mathrm{a}$ & MIQ & $\rightarrow$ & MT3 & 0.041 & 0.226 & $\mathrm{~ns}$ & Rejected \\
\hline $\mathrm{H} 2 \mathrm{~b}$ & MSYQ3 & $\rightarrow$ & MT3 & -0.213 & -1.257 & $\mathrm{~ns}$ & Rejected \\
\hline $\mathrm{H} 2 \mathrm{c}$ & MSQ & $\rightarrow$ & MT3 & 0.808 & 3.493 & $0.001 * * *$ & Accepted \\
\hline $\mathrm{H} 3$ & MATRN2 & $\rightarrow$ & MSAT & 0.637 & 7.401 & $0.001 * * *$ & Accepted \\
\hline $\mathrm{H} 4$ & MT3 & $\rightarrow$ & MSAT & 0.397 & 5.063 & $0.001 * * *$ & Accepted \\
\hline H5 & MT3 & $\rightarrow$ & MLOY4 & 0.058 & 0.565 & ns & Rejected \\
\hline $\mathrm{H} 6$ & MSAT & $\rightarrow$ & MLOY4 & 0.847 & 7.045 & $0.001 * * *$ & Accepted \\
\hline \multicolumn{8}{|c|}{$* * * \mathrm{p} \leq 0.001 ; * * \mathrm{p} \leq 0.01 ; * \mathrm{p} \leq 0.05$} \\
\hline $1 \mathrm{SV}=\mathrm{sn}$ & Avalue, & $y=1$ & & 15 & & lity & \\
\hline
\end{tabular}

Multigroup analysis was conducted to test the moderating effects of gender, age, and level of education on shared value, information quality, system quality, service quality, trust, attraction, satisfaction, and e-loyalty.

These results in table 6 show the moderating effect of gender, age, and level of education. The gender effect suggests that the influence of attraction on satisfaction is significantly higher for females than for a male. In other words, female customers are more prone to attraction in explaining satisfaction. 
Product \& Brand Management, 25(6), 568585.doi.org/10.1108/JPBM-05-2015-0884.

Arpaci, I. (2016). Understanding and predicting students' intention to use mobile cloud storage services. Computers in Human Behavior, 58, 150-157.

Baumann, C., Elliott, G., Hamin, H. (2011). Modelling customer loyalty in financial services: A hybrid of formative and reflective constructs. International Journal of Bank Marketing, 29(3), 247-267.

Benbasat, I., Gefen, D., \& Pavlou, P.A. (2010). Introduction to the Special Issue on Novel Perspectives on Trust in Information Systems. MIS Quarterly, 34 (2), 367-371.

Cappelli, P. and Clancy, J. (1999). Is Loyalty Really Dead? Across the Board, 36, 14-19.

Caruana, A. (2002). Service loyalty: The effects of service quality and the mediating role of customer satisfaction. European Journal of Marketing, 36(7/8), 811-828.

Davis, F.D. (1989). Perceived usefulness, perceived ease of use, and user acceptance of information technology. MIS Quarterly, 13 (3), 319-340.

Echchabi, A., Al-Hajri, \& S., Tanas, I. (2019). Analysis of EBanking acceptance in Oman: The case of Islamic Banks' Customers. IJIEF: International Journal of Islamic Economics and Finance, 1(2), 145-16.

Floh, A., \& Treiblmaier, H. (2006). What Keeps The e-Banking Customer Loyal? A Multigroup Analysis of The Moderating Role of Consumer Characteristics on e-Loyalty in The Financial Service Industry. Journal of Electronic Commerce Research, 7(2): 97-110.

Fornell, C. and Larcker, D.F. (1981) Evaluating Structural Equation Models with Unobservable Variables and Measurement Error. Journal of Marketing Research, 18, 39-50

Fraering, M, \& Minor, M. (2013). Beyond loyalty: Customer satisfaction, loyalty, and fortitude. Journal of Services Marketing, 27(4), 334-344.

Gao. L., \& Waechter, K.A. (2017). Examining the role of initial trust in user adoption of mobile payment services: An empirical investigation. Information Systems Frontiers, 19 (3), 525-548

Gera, R. (2011). Modelling e-service quality and its consequences in India: an SEM approach. Journal of Research in Interactive Marketing, 5(2/3), 203-225.

Gronroos C. (2001), A service quality model and its marketing implications, European Journal of Marketing, Vol. 18 No. 4:36-44.
Hawking, S. W. (1998). A brief history of time: From the big bang to black holes (10th ed.). New York: Bantam Doubleday Dell Publishing Group.

Homburg Christian and Annette Giering (2001), - Personal Characteristics as Moderators of the Relationship Between Customer Satisfaction and Loyalty-An Empirical Analysis. Psychology \& Marketing, 18(1), 43-66.

Jansson, E., \& Letmark, M. (2005). Customer Loyalty in an Internet Banking Context. Institutionen För Ekonomi Och Företagande.

Kandampully, J., Zhang, T. \& Bilgihan, A. (2015). Customer Loyalty: A Review and Future Directions with a Special Focus on the hospitality industry. International Journal of Contemporary Hospitality Management, 27 (3), 379-414.

Kassim, N. M., \& Abdulla, A. K. M. A. (2006). The influence of attraction on internet banking: an extension to the trustrelationship commitment model. International Journal of Bank Marketing, 24(6), 424-442.

Kaur, H., \& Soch, H. (2012), Validating Antecedents of Customer Loyalty for Indian Cell Phone Users. Vikalpa: The Journal for Decision Makers, 37 (4), 47-62.

Kesharwani, A., \& Singh Bisht, S. (2012). The impact of trust and perceived risk on internet banking adoption in India: An extension of technology acceptance model. International Journal of Bank Marketing, 30(4), 303-322.

Khasawneh, Al. M.H., Hujran, O., \& Abdrabbo, T. (2018). A quantitative examination of the factors that influence users' perceptions of trust towards using mobile banking services. International Journal of Internet Marketing and Advertising, 12 (2), 181-207.

Ladhari., R., Souiden, N., \& Ladhari, I. (2011). Determinants of loyalty and recommendation: the role of perceived service quality emotional satisfaction and image. Journal of Financial Services Marketing, 16, 111-124.

Limbu, Y. B., Wolf, M., \& Lunsford, D. I., (2011). Consumers' perceptions of online ethics and its effects on satisfaction and loyalty. Journal of Research in Interactive Marketing, 5(1), 7189.

Matemba, E. D., \& Li, G. (2018). Technology in Society Consumers 'willingness to adopt and use WeChat wallet: An empirical study in South Africa. Technology in Society, 53,5568. doi.org/10.1016/j.techsoc.2017.12.001

Melnyk, V., \& Bijmolt, T. (2015). The effects of introducing and terminating loyalty programs. European Journal of Marketing, 49(3-4), 398-419. doi.org/10.1108/EJM-12-2012$\underline{0694}$ 
Mukherjee, A., \& Nath, P. (2003). A model of trust in online relationship banking. International journal of Bank Marketing, 21(1), 5-15.

Musaev, E., \& Muhammed Yousoof, M. (2015). A Review on Internet Banking Security and Privacy Issues in Oman. ICIT 2015- The 7th International Conference on Information Technology, January 2015.

Ofori, K.S., Boakye, K., \& Narteh, B. (2018). Factors influencing consumer loyalty towards $3 \mathrm{G}$ mobile data service providers: Evidence from Ghana. Total Quality Management \& Business Excellence, 29 (5-6),580-598.

Oliver, R.L., \& Swan, J.E. (1989) Consumer Perceptions of Interpersonal Equity and Satisfaction in Transactions A Field Survey Approach. Journal of Marketing, 53, 21.

Ozturk, A.B., Nusair, K., Okumus, F., \& Singh, D. (2017). Understanding mobile hotel booking loyalty: An integration of privacy calculus theory and trust-risk framework. Information Systems Frontiers, 19 (4), 753-767.

Podsakoff P.M., MacKenzie S.B., Lee Y., \& Podsakoff N.P. (2003). Common method biases in behavioral research: a critical review of the literature and recommended remedies. $J$. Appl. Psychol. 88, 879-903.

Puriwat, W., \& Tripopsakul, S. (2017). The impact of e-service quality on customer satisfaction and loyalty in mobile banking usage: Case study of Thailand. Polish Journal Management Studies, 15(2), 183-193.doi.org/10.17512/pjms.2017.15.2.17.

Reichheld, F.F. and Schefter, P. (2000). E-Loyalty Your Secret Weapon on the Web. Harvard Business Review, 78, 105-113.

Ribbink, D., Riel, A.C.R., Liljander, V., \& Streukens, S. (2004). Comfort your online customer: quality, trust, and loyalty on the internet. Managing Service Quality, 14 (6), 446-56.

Rizomyliotis, I., Konstantoulaki, K., Kaminakis, K., Giovanis, A., \& Papastathopoulos, A. (2018). Antecedents of Customer Loyalty in The Mobile Telecommunication Market A Crosscultural Investigation. Academy of Marketing Studies Journal, $22(4)$.

Robert M. M and Shelby D. H. (1994). The Commitment-Trust Theory of Relationship Marketing Journal of Marketing, 58 (3), 20-38.

Sathye, M. (1999). Adoption of Internet Banking by Australian Consumers an Empirical Investigation. International Journal of Bank Marketing, 17, 324-334.

Sharma G. \& Lijuan W. (2014). Ethical perspectives on ecommerce: an empirical investigation. Internet Research, 24, 414-435.
Silic, M., \& Ruf, C. (2018). The effects of the elaboration likelihood model on initial trust formation in financial advisory services. International Journal of Bank Marketing, 36(3), 572590. doi.org/10.1108/IJBM-02-2017-0038.

Stewart, H., \& Jürjens, J. (2018). Data security and consumer trust in FinTech innovation in Germany. Information and Computer Security, 26 (1), 109-128.

W. Wang, W., Ou, W., \& Chen, W. (2019). The impact of inertia and user satisfaction on the continuance intentions to use mobile communication applications: A mobile service quality perspective. International Journal of Information Management, 44 (2019), pp. 178-193.

X. Zheng, X., Men, J., Yang, F., \& Gong, X. (2019). Understanding impulse buying in mobile commerce: An investigation into hedonic and utilitarian browsing. International Journal of Information Management, 48, 151160.

Yuan, Y., Lai, F. \& Chu, Z. (2019). Continuous usage intention of Internet banking: a commitment-trust model. Information System E-Business Management, 17, 1-25. doi.org/10.1007/s10257-018-0372-4

Zhang, T., Lu, C., \& Kizildag, M. (2018). Banking “on-the-go": Examining consumers' adoption of mobile banking services. International Journal of Quality and Service Sciences, 10 (3) (2018), pp. 279-295.

Zhou, T. (2011d). Examining the critical success factors of mobile website adoption. Online Information Review, 35 (4), 636-652.

Zhou, T. (2012b). Understanding users' initial trust in mobile banking: An elaboration likelihood perspective. Computers in Human Behavior, 28 (4), 1518-1525. 